\title{
Implementation Of The Insya' Lesson To Improve The Writing Skills Of Students In The Senior High School
}

\author{
Abdul Hafidz Zaid ${ }^{1}$, Imam Bahroni' ${ }^{2}$, Putri Retno Sari ${ }^{3}$ \\ \{sariretno2013@gmail.com ${ }^{3}$ \} \\ ${ }^{1,2,3}$ University of Darussalam Gontor, Jl. Raya Siman No.Km. 6, Dusun I, Siman, Kabupaten Ponorogo, \\ Jawa Timur 63471, Indonesia
}

\begin{abstract}
The Insya' lesson is one of the lesson that acquire the language by improving the writing skills. This research is aim to: description of the implementation of the Insya' lesson in the senior high school, the detection of the method of teaching, and the detection of problems faced by teachers and learners. The methodology used is qualitative research. The results of this research are as follows: The implementation of the lesson to train the language skills of the students and to improve the efficiency of students towards learning Arabic language in writing, The methods of teaching this lesson is the direct method, the use of questions, and the method of selectivity, the Problems in teaching this article are problems in terms of the teacher, the method of education, and students, and The solution to problems of teaching this lesson is the completion of duties in terms of teachers and students.
\end{abstract}

Keywords: Writing skill, Insya' lesson, Senior high school

\section{Introduction}

Language learning requires by learn the four language skills: listening skills, speech skills, reading skills, and writing skills.[1] The ability of listening and reading to understand the content is an acquisition skill, but the skill of speech and writing skills to express the content is a applied skill. The last two skills are aimed at teachers of the Arabic language because the correct expression represents the outcome of the student absorbed and stored linguistic elements.[2]

The skill of writing has two terms: the expression of writing and the creation, this an ability to represent the drawing of the linguistic character that people understand when reading it, which is a precise linguistic work, speaking or writing, and caring for the denominator and appropriate to the case.[3] This article is a lesson to train pupils to do all the colors of linguistic activity that the community requires.[4] The teaching of this article requires the ability to write what they hear, what they speak and what they read.

Some of the things that must be done to the teachers in teaching of Insya' lesson are how to understand and performance the duties of the teacher in Insya' lesson , how to teach this article, and the duties of students in learning this article. This is essential for the successful teaching of this lesson. The teacher must learn about the problems faced by himself and that

\footnotetext{
1 The lecturer University of Darussalam Gontor Indonesia

${ }^{2}$ The lecturer in University of Darussalam Gontor Indonesia

${ }^{3}$ The student in University of Darussalam Gontor Indonesia
} 
students are faced with learning about this lesson and how to solve these problems. According to these matters, the discussion will be presented in this paper.

\section{Insya' Lesson And Its Role In The Teaching Of The Arabic Language}

The Insya' is a source of creation and the creation of a further grew up by transgression. The meaning of language is the meaning of creation, as the meaning of height implies. The meaning here is to find and to create not from nothing but another matter.[5] Insya' is the process of expression of ideas in the form of a series according to the system of language synthesis, or the process of transfer between the minds of the generator and the receiver, and the requirements of this process of certain assets and precise conditions and the technical provisions required.[6] The meaning of the other is an expression in a verbal form that suggests the purposes of the speaker, or the stage in which the student is free to choose his ideas, vocabulary, and composition when writing.

It should be distinguished between the terms Insya' and expression (Ta'bir), and it has been found that some educators tend to use the term Insya' and influence it on the term expression (Ta'bir). The word Insya' means creation (Ibda') or creation (al-khalq), creation and creativity is not what everyone wants or prepares for any human being, but it is a matter of education and the need for so-called talent or readiness. The expression (Ta'bir) is broader and more comprehensive than the Insya' because it includes the oral and written, and Insya' is the narrowest circle of adaptation because it is limited to the written side.

The subject of the science of Insya' is the knowledge of the origins of writing and its arts, and the consequent methods of speech and methods of expression, and what must be the culture of origin, to be eloquent in its creation, in terms of strength of installation and injury meaning, and also be the subject about things that fall under the senses and experiences of students And not far from their awareness and emotions, so that they can find all the necessary ideas, for that subject and based on their past information and subsequent observations.

\section{The Foundation In Teaching Insya' Lesson}

\subsection{Psychological Foundations}

One of the psychological foundations in the teaching of the Insya' lesson is: 1) the tendency of the children to express themselves, and to talk to their parents, brothers and friends, and this tendency appears in the child's keenness that his father happens in what he saw together in the funeral home or at a party, the teacher can take advantage of this psychological basis in the treatment of children who refrain from participating in the lesson of expression and intimidate their positions. 2) and the tendency of children to feelings and feelings of morale and take into account this principle is useful in the selection of subjects suitable for students at various stages and the use of images and models during the lesson, 3) and students to express if they have motivation and motivation, and we're in a situation of vulnerability and emotion, 4) During the attempt to express the mind, several mental processes in which there is a lot of difficulty and complexity, the process of analysis and the process of installation. 5) the predominance of the hymn to some students, and 6) imitation.[7]

\subsection{Educational Foundations}

One of the educational foundations in the teaching of the Insya' lesson: 1) Freedom, 2) The expression is not a specific time and not a specific share, but a continuous linguistic activity. (3) The child can not express anything unless he has prior knowledge of this thing, and 
therefore the students narrow some subjects and describe it as closed or narrow or dark and permission should be subject to themes Related to pupils' minds.[7]

\subsection{Language Bases}

Some of the linguistic bases in the teaching of the Insya' lesson are: 1) the lack of linguistic distribution among the students, and this requires working on the development of this crop in the natural way, such as reading and listening, 2) oral expression earlier than written expression, 3) concurrence of general language.[7]

\section{Objectives Of The Insya' Lesson}

One of the aims of Insya' lesson teaching is: 1) to provide learners with the ability to express their meanings and ideas, to articulate soundness and sound structures; 2) to provide learners with the ability to chain ideas and build on one another incoherently coherent sentences; 4) Training learners to overcome the direct expression to the metaphorical artistic expression, especially the talented ones, 5) give the learners the ability to use new meanings and ideas, 6) to familiarize the learners with frankness, and to express the opinion before others, 6) To develop the spirit of criticism and analysis among learners and to familiarize them with good observation and accuracy, and encourage them to discuss. [8]

The purpose of the science of Insya' is to show the origins of writing and to take into account its art so that the interaction between fully interacting minds can be realized.[9] And to prepare an individual who is capable of expressing the life situations he faces, a clear expression of the idea, the net of the language, and the sound performance of the hearer or the reader understands it and finds its intentions. [8] Hence the purpose of the Insya' lesson:

a. Enable pupils to express what they feel or what they are seeing in a sound and correct way

b. Expand the circle of their ideas

c. To supply the missing vocabulary and compositions, in a natural way

d. Accustom them to logical thinking and order ideas and connect

e. prepare them for the vital positions that require eloquence ability to improvise.[7]

\section{The Strategy Of Teaching Of Insya' Lesson}

\subsection{The Strategy Of Choosing The Subject In The Insya' Lesson}

It is necessary to step up with the students in terms of the subjects of expression, start with them what they see, and related to their lives directly, ie, start the school environment and the home environment, and then the external environment. And now go back to talk about the Insya' issues and what should be taken into account in the selection. Here we mention:[10]

a. The subject chosen should be in the students' area of expertise. That means they have things to say. As long as the structural subject is intended to practice writing, students should practice writing ideas and experiences from them.

b. The subject matter has value, whether it is personal values related to students and their welfare, or social value

c. The topic is clearly defined; vague general subjects do not provide the student with an opportunity to organize his ideas.

\subsection{Steps To Teach The Insya' Lesson}

The steps of teaching Insya' are: 
a. Preface. The teacher mentions the title of the subject and hands it on the blackboard, then turns around some questions that indicate the interest of the students and attract their attention, and ask someone to read the introduction written in the book and the collection of information gathering.

b. The teacher reviews the students in the subjects of the subject agreed upon in the share of verbal editing and then writes them on the side of the blackboard, and these elements are reviewed with students quickly, and discussed and explained, through the information collected by students. And then discuss with them the conclusion of the subject, and asks them to bite the conclusion of the conclusion they wrote.

c. Write the subject. The teacher asks the students to put aside the drafts and papers in which they have collected the information and then distributes them to the written expression of intentional writing to write the expressions in the class, and each student begins to write deliberately on himself and his memory and the collection of information and concise in mind, Guide and teacher and remind them of the basics of writing the subject of written expression. After that, the teacher collects the books in the last minutes of the lesson and then begins the correction process according to the foundations of correct and educational correction, so that each student recognizes the strengths and weaknesses in the performance.

d. Evaluation. The teacher evaluates the students' subjects according to a set of criteria. The teacher should agree with the students before writing so that they are suitable for the quality of the subjects proposed and for the objectives of the expression in general.[11]

\section{Research Methodology}

The methodology used in this research is descriptive qualitative research methodology for obtaining research in the implementation of the Insya' lesson in improving the efficiency of writing skill in the senior high school. Therefore, the desired data in this research is obtained through observation, interviews, and documents.

Observation is the method of observation or observation that involves focusing attention on the intent.[12] The researcher used this method to observe the linguistic aspect of students at the secondary level. The interview method is the process of recognizing the data for the research in the form of the questions and answers between the interviewer and the corresponding interviewer.[12] It is a tool for collecting information by providing several questions orally to answer verbally as well. The main feature of interviews is in direct contact with face-to-face information seekers and information sources. Use this method to obtain data from the result of the interview with some teacher or teacher at a senior high school.[13] The documents are a tool for collecting data in the form of events consisting of writing, drawing, or large works from a person or institution, view and analyze data.[14]

\section{View and analyze data}

\subsubsection{Implementation Of The Insya' Lesson In The Senior High School At The Boarding School Of Walisongo Ngabar Ponorogo}

The Insya' lesson is a language lesson or a language application course. It also trains pupils to apply the language lesson and grammar. Therefore, students should follow models in case of syntax or language use.[15] It is one of the lessons for students at the Boarding School of Walisongo Ngabar Ponorogo, from the second grade to the sixth grade of the regular classes, the third grade of the intensive classes, and the important foundations for training the 
language skills of the students and improving the students' proficiency in learning the Arabic language in terms of writing. The study of the Insya' at the Boarding School of Walisongo Ngabar Ponorogo, is here under the supervision of the teacher in the complex classes during learning and teaching in the classroom or outside the classroom. This exercise will continue with the help of the homework and the surrounding environment and the defender of language activities.

Educational activities start at the Boarding School of Walisongo Ngabar Ponorogo from Saturday to Thursday from 07:00 to 13:00 WIB. The Insya' lesson comes twice a week, every 40 minutes. The school places this course as a course for students in the second to sixth grade and considers it a basic subject in the teaching of the Arabic language, especially in the teaching of writing skills.

And the curriculum of teaching the establishment in this Institute of the curriculum of the Islamic study where the curriculum of the study of this Institute of two types, the curriculum of Islamic study and the methodology of the cosmic study. These two approaches are important in the formation of students' ethics and the development of their language proficiency, particularly in Arabic and English, because the teacher and students must speak in the previous two languages in the teaching room or outside.

The purpose of teaching the Insya' lesson is:

a) The ability to express the right based on the grammar

b) Accuracy in the use of the word and its structure in the sentence and phrase

c) Use good and good taste in the syntax of the sentence

d) Students to think properly and logical thinking

e) Freedom of thought and strengthening of the senses

f) To familiarize students with the ability to form good opinions and ideas

g) Strengthen the queen of honest observation and queen of thought.

\subsection{Method Of Teaching Insya' Lesson In The Intermediate Stage}

How the Insya' lesson is taught to students at the senior high school of the Boarding School of Walisongo Ngabar Ponorogo:

a. Direct method. This method is the principle of the step of the school in teaching when the school gave the new subject, so many of the school uses this method of teaching Arabic.

b. The way using the questions. This method is used when students answered questions or exercises in the book. It is essential that the teacher use this method to find out how well students can understand them.

c. The method of research, which is to conduct the students who are teaching in the teacher's teaching.

d. Synthesis Method: a method used when the teacher asked students to make the appropriate sentence.

e. Method of selectivity: the sporadic and used method of teaching the school in class. To achieve the goal of education, the success of education, the teacher should be concerned about the important things that are desired in education and the method used.

\subsection{Problems Faced By Teachers And Students In Teaching And Learning The Insya' Lesson}

The problems faced by the teacher in the Insya' lesson is the preparation of the lesson, and this because of his qualifications in Islamic studies, he knows how to build good in Insya' lesson but did not learn how to teach good Insya' lesson . 
The problems in teaching of Insya' lesson itself are the design of the lesson, lack of references and sources, weak knowledge of teaching methods, diversity of students 'efficiency and requirements, use of teaching aids, writing students' creation unreadable and incomprehensible. Students believe that the teacher is good at providing the lesson, patient in their education and tolerant, encouraging them to discuss and exchange views and respect their opinions. But is weak in the preparation of the lesson and the use of methods and the use of means.

In the students, the lesson they learned was not clear and ineffective. They were not organized with repetition in the training and did not care about the stages of learning the Insya', and did not hesitate from easy to difficult, and vice versa, so that they feel guilty and bored to not organize the good lesson.

\subsection{Attempts To Solve Problems In Teaching Insya' Lesson.}

To solve previous problems, the teacher should know his or her duties in teaching Insya'. The duties of the teacher either towards himself or his students varied and many, as it is a major source in the impact of students towards the lesson, and these duties:

a. to have some knowledge and science so that he can correctly judge the ideas of his students and the information they provide in the lesson.

b. to have many experiences through visits and trips and see the manifestations of nature.

c. The teacher does not cost his students in matters that are unknown to them, far from their science, and that the ideas presented to them are clear and not ambiguous because the clear thought affects the clarity of expression.

d. The teacher to explain the meanings of the words and their functions in the sentence, and provides the opportunity to build clear sentences in their significance.[16]

It is necessary to observe the teacher in the education of Insya':

a) of the standards of good writing to coordinate the organization of the lesson and the content corresponds to what is in the mind of the individual goal, was one of the first steps of teaching the definition of students permanently the goal of writing. Few students know exactly what they mean by writing, while many know their purpose of speaking or reading.[17]

b) Student copies should be supervised by the teacher.[18]

c) Not all exercises are as easy as that, so the teacher should choose from them what suits the linguistic level of his students.

d) The restricted writing exercise must come after the teacher has explained the structure he is working on and the training of the students.[19]

e) The student should not be given anything to write unless he has written it and heard it.[18] The assignment of the student to write new words or unfamiliar structures or write words that differ from the pronunciation of the writing will hamper the writing itself and the loss of time and effort.

f) The teacher should not impose on students a set of stereotypes that they are committed to in the subjects of expression, but be capable of what their segments of the vocabulary, structures, and ideas corrected correctly them, it is better to memorize a set of structures that then become clichés spread in every subject.

g) After the students write the exercise, it is corrected by self-correction. Each student corrects what he wrote by comparing the typical answers, or by correcting the teacher for what each student wrote. 
h) The teacher should discuss with his students their common mistakes and give them more exercises and exercises to address these errors.

i) Each student rewrites the whole exercise or the wrong sentences only.

j) Homework must be limited to writing on what the students have learned in the classroom and the teacher will make sure they find their work on their own.

The students' duties towards themselves in the Insya' lesson are:

a) Accuracy in the observation of things, and describe them as methodically sound.

b) based on a good sense and good to help him in selecting the word and sentence and the appropriate expression.

c) clarity of thinking, so that the main ideas are determined and organized before writing.

d) Accuracy in discussing ideas and issues after a presentation.

e) Proficiency in the grammar of the composition, drafting, dictation, and calligraphy.

f) to keep away from the dry narrative, but must use the calibrated actions, dialogue, and simple balances.

g) Use Quotations correctly, so that they can be used to confirm, deny or discuss the idea.

h) Accuracy in the use of punctuation, margins, and paragraphs.

\section{Closing}

According to previous research, the researcher wanted to draw the following:

1. The implementation of teaching Insya' lesson at the Boarding School of Walisongo Ngabar Ponorogo in the senior high school to train the language skills of students and to improve the efficiency of students towards learning Arabic in terms of writing. The objectives of teaching this article are: the ability to express the correct basis of the grammar, accuracy in the use of the word and its composition in the sentence and sentence, the use of good and good taste in the syntax of the sentence, to familiarize students to sound thinking and logical thinking, freedom of thought and strengthen the senses, And to familiarize students with the ability to form good opinions and ideas, and strengthen the queen of sincere observation and Queen of thought.

2. Methods of teaching the Insya' lesson at the Boarding School of Walisongo Ngabar Ponorogo in the senior high school are direct method way, the way they use of questions, the method of exploration, the method of synthesis, and the method of selectivity.

3. The problems faced by teachers are the design of the lesson, lack of references and sources, weak knowledge of teaching methods, diversity of students 'efficiency and requirements, use of teaching aids, writing students' creation unreadable and incomprehensible. Students believe that the teacher is good at providing the lesson, patient in their education and tolerant, encouraging them to discuss and exchange views and respect their opinions. But is weak in the preparation of the lesson and the use of methods and the use of means. In the students, the lesson they learned was not clear and ineffective. They were not organized with repetition in the training and did not care about the stages of learning the Insya', and did not hesitate from easy to difficult, and vice versa, so that they feel guilty and bored to not organize the good lesson.

4. Attempts to solve these problems are to meet the duties of the teacher and the students and know how to teach the appropriate manner of this article. 


\section{Acknowledgment}

The authors would like to express their thanks to:

1. Kemenristekdikti for their support by Research Program for Magister Theses.

2. The anonymous for their constructive comments and suggestions

\section{References}

[1] H. Aydoğan, "The Four Basic Language Skills, Whole Language \&amp; Intergrated Skill Approach in Mainstream University Classrooms in Turkey Hakan Aydoğan Associate Professor Azamat A. Akbarov," print) Mediterr. J. Soc. Sci. MCSER Publ., vol. 5, pp. 2039-2117, 2014.

[2] A. Muradi, "WÂQI' TA'LÎM MAHÂRAH AL-KITÂBAH BI INDÛNÎSIYYÂ MUSYKILATAN WA HULÛLAN," Arab. J. Pendidik. Bhs. Arab dan Kebahasaaraban, vol. 5, no. 1, 2018.

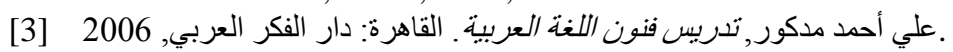

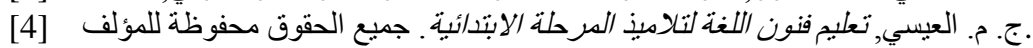

[5] S. Prihantoro, "Analisis Kesalahan Bahasa Pada Taksonomi Linguistik Dalam Penulisan Insya"," al Mahāra J. Pendidik. Bhs. Arab, vol. 5, no. 1, pp. 41-62, 2019.

[6] D. Masqon, Y. Suryadarma, and A. F. Abdullah, "Analisis Problematika Pembelajaran Insya' Arabi at-Tahriri Santri Kelas Lima Kulliyatul Mu'allimin Al-Islamiyah (KMI) Di Pondok Modern Gontor Dua," At-Ta'dib, vol. 12, no. 2, p. 139, 2017.

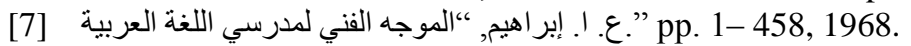

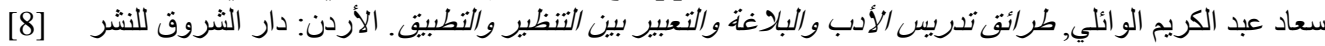

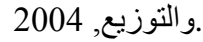

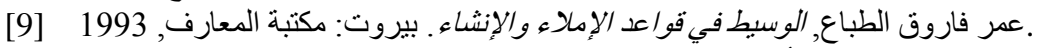

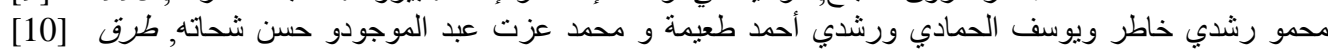
تدريس اللغة العربية والتربية الدينية في ضوء الاتجاهات التربوية الحديثة, الطبعة الس. الكويت: مؤسنة الكتب الكب

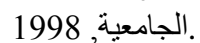

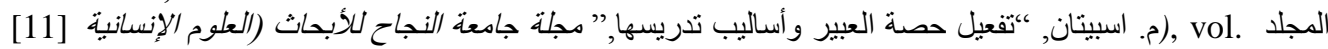

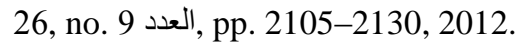

[12] U. Flick, "From Research Idea to Reseach Question," in Introducing Research Methodology: A Beginner's Guide to Doing a Research Project, 2015, pp. 45-55.

[13] Margono, Metodologi Penelitian Pendidikan, 4th ed. Jakarta: Rineka Cipta, 2004.

[14] Sugiyono, Metode Penelitian \& Pengembangan: (Research and Development/R\&D). Bandung: ALFABETA, 2015.

Ponorogo: Trimurti Gontor.

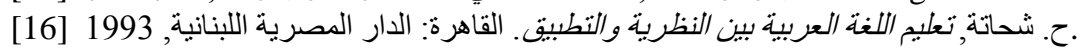

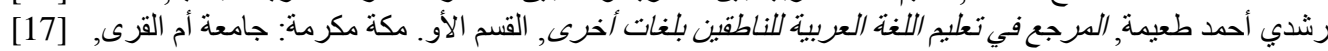
1986.

رشدي أحمد طعيمة ومحمود كامل الناقة, تعليم العربية لغير الناطقين بها الكتاب الأساس, الجزء الأو. القاهرة: جامعة [18]

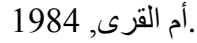

محمد على الخولي, “أساليب تدريس اللغة العربية.” المملكة العربية, الرياض [19. p. 139, 1989.

[20] Somov, A.: Wildfire safety with wireless sensor networks. EAI Endorsed Transactions on Ambient Systems. pp. 1-11 (2011) 
[21] Motaz, A.: Start programming using Object Pascal. Vol. 2, pp. 10-11. Legally Free Computer Books, US (2013) 